\title{
Relațiile dintre lamarckism și darwinism; neolamarckism ${ }^{\dagger}$
}

\author{
Alpheus Spring Packard
}

De la apariția Originii speciilor, a lui Darwin, și după ce marele naturalist a convertit lumea la credința în doctrina generală a evoluției, în mintea multor naturaliști activi a apărut convingerea că selecția naturală, sau darwinismul ca atare, este doar unul dintre factorii evoluției, în vreme ce unii au respins pe de-a întregul principiul selecției. De altfel, Darwin a presupus existența unei tendințe către variația întîmplătoare, fără a încerca să-i explice cauza. Pe deplin convins că descoperise cea mai eficientă și, practic, singura cauză a originii speciilor, el și-a dus doctrina la ultimele ei consecințe și, după mai mult de douăzeci de ani de observație și expriment doar în această direcție, dînd pe de-a întregul deoparte factorii de schimbare a mediului, ai lui Erasmus Darwin și Lamarck-deși, ocazional, a recunoscut importanța întrebuințării și neîntrebuințării-, a zdrobit triumfător orice opoziție şi a trăit să-și vadă doctrina general acceptată. În plus, el a avut sprijinul unora dintre cei mai puternici oameni de știință ai vremii: într-o lucrare geamănă, Wallace a susținut aceleași opinii; Spencer, Lyell, Huxley, Hooker, Haeckel, Bates, Semper, Wyman, Gray, Leidy și alți bărbați de seamă au fost de acord, mai mult sau mai puțin, cu viziunea lui Darwin, sau cel puțin cu o formă a evoluției, astfel încît, în mare parte datorită efortului lor în cercurile științifice și în presa curentă, doctrina evoluției s-a imprimat în toate modalitățile de a gîndi și a ajuns să fie general acceptată.

Între timp, doctrina generală a evoluției fiind astfel demonstrată, iar „supraviețuirea celui mai adaptat" fiind un fapt împlinit, următorul pas a fost de a determina, în termenii întrebării lui Cope, „cum a apărut cel mai adaptat"? Unii au simțit că doctrina selecției naturale nu este adecvată pentru a explica singură primii pași ai apariției genurilor, familiilor, ordinelor, claselor și încrengăturilor sau filelor. Unii au sesizat că selecția naturală în sine nu era o vera causa, un agent eficient, ci unul pasiv, mai degrabă exprimînd rezultatele acțiunii unei serii de factori.
Transformarea ar trebui să preceadă în mod natural acțiunea agenților selecției.

Așadar, căutînd factorii evoluției organice, ne vedem obligați să revenim la acțiunea forțelor fizicochimice, precum lumina sau absența ei, căldura, frigul, schimbarea climei, şi la factorul fiziologic al hranei, cu alte cuvinte, deopotrivă la schimbările mediului fizic și ale celui biologic. Datorită anilor îndelungați de exerciţiu în botanica și zoologia sistematice, apoi a amplei sale dimensiuni filozofice, Lamarck a fost primul care, într-un mod mai deplin şi mai magistral decît oricine, a determinat consecințele schimbărilor în acțiunea factorilor primari ai evoluției. De aici, revenirea multora din Europa și mai ales din America la lamarckism sau la forma sa modernă, la neolamarckism. Atît cît a putut, fără cunoașterea morfologiei moderne, a embriologiei, a citologiei și histologiei, Lamarck propusese deja principiile fundamentale ale transformismului, pe care se întemeiază principiul selecției.

Dacă lucrările lui Lamarck ar fi fost mai accesibile sau, la îndemînă fiind, dacă ar fi fost citite cu mai multă atenție, iar opiniile sale mai obiectiv prezentate, dacă ar fi fost sprijinit în timpul vieții de un singur susținător măcar, iar nu criticat pe nedrept de către Cuvier, știința ar fi progresat mai repede, întrucît este un adevăr axiomatic acela că acceptarea generală a unei teorii evoluționiste valide a impulsionat cu putere biologia.

Vom oferi un scurt sumar istoric al evoluției opiniei susținute de către lamarckieni, cu privire la cauzele „apariției celui mai adaptat”, la apariția variațiilor şi la manifestarea unei populații de plante și de animale îndeajuns de răspîndite și de diferențiate încît să permită jocul forțelor concurențiale și al mai pasivelor forțe selective care au început să opereze în perioada precambriană sau imediat ce pămîntul a devenit potrivit pentru existența ființelor vii.

Primul autor de după Lamarck care a mers pe urmele întemeiate de acesta a fost Herbert Spencer.

${ }^{\dagger}$ Traducerea primei părți (p. 382-396) a capitolului XX al lucrării Lamarck, the Founder of Evolution, his Life and Work, with Translations of his Writings on Organic Evolution, New York, London, Bombay, 1901. 
În epocalele și extraordinar de sugestivele Principles of Biology, din 1866-1871, vorbind despre efectele mișcării asupra structurii, în general ${ }^{1}$, a implicat doctrina întrebuințării și neîntrebuințării; iar prin teoria sa cu privire la originea notocordului, a segmentării coloanei vertebrale și a aranjamentului segmental al mușchilor ca urmare a tensiunii musculare ${ }^{2}$, a pus bazele cercetărilor viitoare în această direcție. În aceeași lucrare, Spencer a mai atras atenția asupra dezvoltării complementare a părților și, de asemenea, a folosit scăderea mărimii mandibulei la rasele civilizate ale omenirii pentru a ilustra o schimbare de care nu este responsabilă selecția naturală a variațiilor favorabile ${ }^{3}$. În fapt, această lucrare se întemeiază în mare măsură pe principiile lamarckiene, considerate a constitui baza pe care se întemeiază acțiunea selecției naturale. Treizeci de ani mai tîrziu avea să afirme: „Acțiunea directă a mediului a fost factorul primordial al evoluției organice" ". In binecunoscuta sa cercetare The Inadequacy of Natural Selection (1893), cu obişnuita-i vigoare şi forță, marele filozof critică argumentele celor care se întemeiază aproape în exclusivitate pe darwinism-și în special pe neodarwinism-, privit ca factor suficient, în măsură să dea seama de originea structurilor speciale și a speciilor, deopotrivă.

Primul autor german care a fost conștient de valoarea factorilor lamarckieni a fost prolificul și comprehensivul filozof și cercetător Ernst Haeckel, care, totodată, a armonizat lamarckismul și darwinismul în următoarea formulă:

„În temeiul importantelor dovezi tocmai enumerate, ar trebui să adoptăm teoria evoluției, a lui Lamarck, drept explicație a fenomenelor biologice, chiar dacă nu am deține teoria selecției naturale, a lui Darwin. Una este atît de deplin și de direct demonstrată de cealaltă, și temeinicită prin cauze mecanice, încît nu ne mai rămîne nimic de dorit. Legile moștenirii și adaptării sînt fapte fiziologice universal recunoscute, cea dintîi putînd fi urmărită la nivelul generațiilor, cea din urmă în hrănirea organismelor. Pe de altă parte, lupta pentru existență este un fapt biologic, ce decurge cu necesitate matematică din disproporția generală dintre numărul mediu al indivizilor organici și excesul numeric al semințelor lor" ${ }^{5}$.

Cam în aceeași vreme, ca urmare a studiilor efectuate în diferite direcții, cîțiva naturaliști americani-nedominați de o prea fermă credință în eficacitatea selecției naturale și întemeindu-se doar pe metoda inductivă - au continuat să lucreze la dovada în favoarea factorilor primari ai evoluției, în direcție lamarckiană, dar în mod independent, întrucît, cel puțin la început, nici Hyatt, nici Cope nu citiseră scrierile lui Lamarck.

În 1866, profesorul A. Hyatt a publicat primul dintr-o serie de studii clasice asupra relațiilor genetice la fosilele cefalopode. Strădaniile sale, atît de bogate în rezultate, au fost continuate timp de patruzeci de ani și sînt acum completate prin munca migăloasă și îndelungată a lui Steinheim asupra bureților, a scoicilor din Terțiar și a scoicilor din Insulele Hawaii.

Primul său articol s-a referit la paralelismul dintre diferitele etape din viața individului și cele ale amoniților, ducînd pînă la capăt descoperirea lui d'Orbigny asupra stadiilor embrionic, tînăr, adult și vîrstnic la amoniți ${ }^{6}$ și arătînd că, la nivelul exemplarelor mature, aceste forme se datorează unei accelerări a creșterii, iar la nivelul celor senile, unei încetiniri a creșterii.

În memoriul „Biological Relations of the Jurassic Ammonites" ${ }^{\prime}$, el leagă cauzele schimbării progresive a acestor forme, apariţia noilor genuri și producerea de forme tinere, mature și senile de „natura favorabilă a ambianței fizice, care, inițial, produce schimbări caracteristice, care ajung să se perpetueze și să se amplifice prin moștenirea lor în cadrul grupului”.

Studiul modificărilor formelor terțiare de Planorbis, al lui Steinheim, început de către Hilgendorf, a condus printre altele (nouă, în total) la următoarele concluzii:

„În primul rînd, formele spirale asimetrice ale cochiliilor acestora și ale tuturor moluștelor rezultă, probabil, din acțiunea legilor eredității, modificate de gravitație.

În al doilea rînd, la aceste scoici şi la alte grupe apar numeroase caracteristici datorate doar acțiunii uniforme a influenței fizice a ambientului imediat, variind în funcție de loc, dar constante și uniforme

\footnotetext{
${ }^{1}$ Vol. II, p. 167, 1871.

${ }^{2}$ Vol. II, p. 195.

${ }^{3}$ Vol. I, \$166, p. 456.

${ }^{4}$ The Factors of Organic Evolution, 1895, p. 460.

${ }^{5}$ Schöpfungsgeschichte, 1868, The History of Creation, New York, II, p. 355.

${ }^{6}$ Alcide d'Orbigny, Paléontologie française, Paris, 1840-1859.

${ }^{7}$ Rezumatul este publicat în „Proceedings of the Boston Society of Natural History”, XVII, 16 dec., 1874.
} 
în fiecare loc.

În al treilea rînd, legea darwiniană a selecției naturale nu explică aceste relații, ci se aplică doar primelor stadii ale constituirii diferenţelor dintre formele sau speciile din același loc. Ceea ce face ea este să fixeze aceste diferențe de organizare și să le aducă în raza de acțiune a legilor eredității”.

Aceste opinii sînt reiterate în ultimele sale articole de paleontologie. Opiniile lui Hyatt asupra accelerării au fost adoptate de către Neumayr ${ }^{8}$. Din studiile sale asupra cefalopodelor din Jurasic, Waagen? concluzionează că factorii care au determinat evoluția acestor forme au fost schimbările de la nivelul condițiilor externe, izolarea geografică, concurența, și că legea fundamentală nu este aceea a lui Darwin, ci „legea evoluției”. Hyatt a mai arătat că, la început, evoluția a fost rapidă. „Evoluția este o chestiune pur mecanică, acțiunea habitatului fiind agentul activ al tuturor schimbărilor majore, la început acționînd, de regulă, asupra stadiilor adulte, iar apoi, prin ereditate, asupra stadiilor timpurii ale generațiilor succesive”. El mai arată că formele primitive migrează și ocupă arii noi, anterior pustii, unde întîlnesc condiții noi, organismele „schimbîndu-și cu repeziciune deprinderile și structurile, spre a se acomoda noilor condiții” ${ }^{10}$.

În timp ce datele paleontologiei procură dovezi complete și numeroase ale acțiunii modificatoare a schimbărilor din mediu, în 1877 , prin studile sale asupra bureților ${ }^{11}$, Hyatt arată că originea nesfîrșitelor forme ale acesora „poate fi explicată numai prin acțiunea mediului fizic, care acționează direct asupra organizării și, pe calea unei astfel de acțiuni directe, produce modificările sau variațiile comune mai sus descrise".

Dl Agassiz subliniază că efectul pe care îl are tipul fundului mării asupra bureților şi rizopodelor „este un factor vital în modificarea organismului" ${ }^{12}$.
În vreme ce studiile lui Hyatt se refereau mai ales la amoniți, moluște și la bureții existenți, Cope a cercetat batracienii. Lucrarea sa Origin of Genera a apărut la scurtă vreme după primul articol al lui Hyatt, dar în acelaşi an (1866). Ea a fost urmată de o serie de cercetări remarcabil de sugestive, întemeiate pe extinsa lui activitate în domeniul paleontologiei, care sînt parțial retipărite în a sa Origin of the Fittest (1887), în timp ce în lucrarea epocală The Primary Factors of Organic Evolution (1896), el ne oferă în formă condensată o expunere clară a unora dintre factorii lamarckieni, în forma lor modernă, neolamarckiană.

În Introducere, la p. 9, el remarcă:

„În aceste scrieri ale Profesorului Hyatt și ale mele se află prima încercare de a arăta prin exemple concrete de taxonomie naturală că variațiile care apar în evoluție nu sînt variate sau eterogene, ci definite și directe, contrar metodei care nu caută o altă origine a variațiilor decît selecția naturală. Cu alte cuvinte, aceste scrieri constituie primele cercetări de evoluție sistematică. Prin descoperirea succesiunii paleontologice a modificării articulațiilor la scheletul vertebratelor și în special al mamiferelor, am furnizat pentru prima dată o dovadă concretă a caracterului real al factorului lamarckian al întrebuințării și neîntrebuințării sau al mișcării ca fricțiune, impact și tensiune - cauză eficientă a evoluției ${ }^{13}$ ".

Discuția din lucrarea lui Cope, asupra kinetogenezei sau a efectelor întrebuințării și neîntrebuințării, procură o serie extinsă de fapte care sprijină acești factori lamarckieni. Cum aceste două lucrări sînt accesibile oricui, doar vom trimite cititorul la ele ca la niște depozite de fapte de ordin neolamarckist.

Pe baza unui studiu asupra dezvoltării și a anatomiei limulușilor și a artropodelor ancestrale, autorul scrierii de față a adoptat devreme $(1870)^{14}$ opiniile lamarckiene, în defavoarea teoriei selecției naturale,

\footnotetext{
${ }^{8}$ "Zeitschrift der deutschen geologischen Gesellschaft”, 1875.

${ }^{9}$ Palaontologica Indica. Jurassic Fauna of Kutch, I, Cephalopoda, în „Memoirs of Geological Survey of India, Calcutta, 1875, p. 242243 (a se vedea Genesis of the Arietide, p. 27, 42, a lui Hyatt).

${ }^{10}$ Genera of Fosil Cephalopods, în „Proceedings of the Boston Society of Natural History”, XXII, 4 apr., 1883, p. 265.

${ }^{11}$ Revision of the North American Porifere, în „Memoirs of the Boston Society of Natural History”, II, partea a IV-a, 1877.

${ }^{12}$ Three Cruises of the Blake, 1888, II, p. 158.

${ }^{13}$ Prima lucrare în care a adoptat doctrinele lamarckiene ale întrebuințării și efortului a fost Methods of Creation of Organic Types, 1871. Aici, Cope subliniază că el „nu 1-[a] citit niciodată pe Lamarck în franceză, și nici nu [a] văzut o expunere a teoriei sale în engleză, cu excepția foarte puținelor remarci din Originea speciilor și din Chambers' Encyclopedia, acestea din urmă [fiindu-i cunoscute] ulterior primei corecturi a acestei lucrări”. Este interesant de observat ce lamarckian desăvîrșit era Cope, în ceea ce privește opiniile sale referitoare la teoria evoluției.

${ }^{14}$ „Proceedings of the American Association for the Advancement of Science”, Troy meeting, 1870, tipărit în aug., 1871.
} 
care niciodată nu i-a părut a fi adecvată sau îndeajuns de cuprinzătoare pentru a explica originea variațiilor.

În anul următor, pe baza unui studiu al insectelor și al altor animale din Peștera Mamutului ${ }^{15}$, am susținut că „trăsăturile care separă genurile și speciile de animale sînt cele moștenite de la adulți, modificate de mediul fizic și de adaptările la condițiile schimbătoare de viață, în măsură să inducă anumite alterări ale părților, care s-au transmis cu o viteză mai mare sau mai mică, în cele din urmă fixîndu-se și devenind obişnuite”.

Într-o cercetare intitulată The Ancestry of Insects ${ }^{16}$ (1873), am adoptat factorii lamarckieni ai schimbării deprinderilor și mediului, ai întrebuințării și neîntrebuințării, pentru a explica originea fanerelor, în vreme ce originea metamorfozelor la insecte am atribuit-o schimbării deprinderilor sau a temperaturilor anotimpurilor și climatelor, cu deosebire schimbării de climă din primele epoci ale Pămîntului, „cînd temperatura globului era aproape aceeaşi peste tot, pînă în vremea actualei distribuții zonale a căldurii și a frigului".

Continuînd studiile asupra animalelor de peșteră, publicate în $1877^{17}$, am scris următoarele: „În producerea speciilor de peșteră, dominația întunericului, lipsa hranei îndestulătoare și temperatura constantă au fost în mod evident suficiente vere cause. A spune că principiul selecției naturale este cauza schimbării de structură nu înseamnă a explica fenomenele; privitor la producerea organismelor de peșteră, aceasta nu are sens pentru noi, și este tot atît de fără sens și în privinţa apariției speciilor și a genurilor, în general. Sintagma lui Darwin, selecție naturală sau supraviețirea celui mai adaptat, a lui Herbert Spencer, exprimă pur şi simplu rezultatul final, în vreme ce procesele de apariție a noi forme, care au supraviețuit sau au fost selectate de către natură, trebuie explicate prin acțiunea mediului fizic al animalelor, în conjuncție cu capacitatea de a moșteni. Întodeauna am considerat că secvențele citate mai sus au fost greșit folosite pentru a arăta cauza, în vreme ce ele exprimă pur și simplu rezultatul acțiunii unui lanț cauzal, pe care, împreună cu Herbert Spencer, îl putem numi mediul organismului supus modificării. În felul acesta, o formă de lamarckism, în mare măsură modificat de recentele descoperiri științifice, pare a depăşi majoritatea dificultăţilor ivite în calea explicării originii speciilor şi a marilor grupe de organisme. Cu siguranță, selecția naturală sau supraviețirea celui mai adaptat nu este vera causa, deși lupta pentru existență ne-ar putea arăta cauzele care au dus la menținerea speciilor, în vreme ce schimbările din mediul de viață al organismului pot da seama în mod satisfăcător de tendința originară către variație, considerată de către de Dl Darwin drept punct de plecare de la care selecția naturală începe să acționeze”.

În lucrarea noastră The Cave Animals of North America ${ }^{18}$, după ce am susținut că Darwin, în Originea speciilor, a atribuit pierderea ochilor "pe de-a întregul neîntrebuințării”, am observat (p. 142) că, după pierderea mai mult sau mai puțin completă a ochilor, „selecția naturală efectuează adesea și alte schimbări, precum o creștere a lungimii antenelor, drept compensație pentru orbire", și am concluzionat asupra următoarelor cauze ale producerii faunei de peșteră, în general:

„1. Schimbarea din mediu, de la lumină, chiar parțială, la semiîntuneric sau întuneric deplin, cu implicarea scăderii hranei, și compensarea pierderii anumitor organe prin hipertrofierea altora.

2. Neîntrebuințarea anumitor organe.

3. Adaptarea, care dă formelor mai plastice posibilitatea de a supraviețui și de a-și perpetua neamul.

4. Izolarea, care împiedică încrucișarea cu forme din afară și, în felul acesta, asigură continuitatea noilor varități, specii sau genuri.

5. Ereditatea, care - atîta vreme cît se păstrează întocmai condițiile fizice - operează în direcția asigurării pe viitor a continuității formelor nou apărute.

Selecția naturală reprezintă mai degrabă rezultatul deplin al acestor cinci factori activi ori, cel puțin, constituie termenul ultim dintr-un şir de cauze, nu o cauză eficientă. Prin urmare, lamarckismul în formă modernă, sau, cum l-am denumit noi, neolamarckis-

\footnotetext{
${ }^{15}$ „American Naturalist”, V, dec., 1871, p. 750. A se vedea și p. 751, 759, 760.

${ }^{16}$ Tipărită în avans, și constituind capitolul al XIII-lea al lucrării noastre Our Common Insects, Salem, 1873, p. 172, 174, 179, 80, 181,185 .

${ }^{17}$ A New Cave Fauna in Utah, în „Bulletin of the United States Geological Survey”, III, 9 apr., 1877, p. 167.

${ }^{18}$ „Memoirs of the National Academy of Sciences”, IV, 1888, 156 p., 24 pl. A se vedea și „American Naturalist”, sept, 1888, XXII, p. 808 și sept, 1894, XXVIII, p. 333.

${ }^{19}$ Carl H. Eigenman, în elaboratul său studiu, The Eyes of the Blind Vertebrates of North America, din „Archiv für Entwickelungsmechanik der Organismen”, VIII, 1899, concluzionează că perspectiva lamarckiană, cea conform căreia ochii peștilor orbi se reduc prin
} 
mul, ni se pare a fi mult mai aproape de adevăr decît darwinismul propriu-zis sau selecția naturală ${ }^{19}$ ".

Într-o încercare de a aplica principiul lui Lamarck la originea țepilor și a coarnelor omizilor, a altor insecte și a altor animale, ca rezultat al stimulilor externi ${ }^{20}$, nu am citit atunci ceea ce spune el în această chestiune. Totuși, ajungînd să examinăm această chestiune, din ceea ce susţin cercetători recenți, mai cu seamă Henslow, și din observaţia că Lamarck a avut dreptate în mare măsură atunci cînd a presupus că sîngele („fluidele” sale) afluează în părțile zonelor expuse ale organismului, ceea ce cauzează apariția coarnelor, conform principiului ubi irritatio, ibi affluxus, înțelegem că:

„Factorii lamarckieni, (1) schimbarea (atît directă, cît și indirectă) mediului, (2) nevoia și (3) deprinderea, și de acum general adoptatul principiu conform căruia o modificare a funcției induce modificări în organe $e^{21}$-iar în unele sau în multe cazuri chiar induce hipertorfierea și specializarea a ceea ce altminteri ar constitui părți sau organe obişnuite-, au importanță deplină în evoluția culorilor, a ornamentelor și a excrescențelor din cuticulele omizilor”.

Actuala noastră opinie asupra relațiilor dintre factorii lamarckieni și cel darwinian, al selecției naturale, este reflectată în rezumatul care urmează:

„1. Cei mai proeminenți tuberculi şi țepii sau perii care apar sînt veruci pilifere hipertrofiate, verucile împreună cu perii pe care îi prezintă fiind comuni tuturor omizilor.

2. Este probabil (poate că ar fi mai bine să spunem posibil) că, inițial, hipertrofia sau creșterea sa datorat schimbării spaţiale, și anume trecerii de la ierburi la copaci, schimbare avind printre consecințe accesul la un aer de o mai bună calitate, o temperatură mai constantă, poate o hrană diferită sau mai bună.

3. Datorită fluidelor nutritive, tuberculii măriţi şi specializaţi s-au dezvoltat mai repede pe un anumit segment decît pe alţii, în special pe segmentele mai proeminente, deoarece fluidele nutritive tind să hră- nească părțile mai expuse la stimuli externi.

4. Stimulii se datorează în mare parte vizitării de către insecte şi păsări, ceea ce determină mimetismul țepilor şi al proeminențelor faţă de copaci; culorile (dungi și pete) se datorează luminii sau umbrei, cu rezultatul general al mimetismului protector sau al adaptării la viața arboricolă.

5. Ca rezultat al unui factor necunoscut, unele dintre celulele hipodermice de la baza țepilor se specializează, la unele forme, astfel încît secretă un fluid otrăvitor.

6. După ce aceste forme primitive, membri ai diferitelor familii, s-au stabilit pe copaci, s-a declanșat un proces de segregare arboricolă sau de izolare, încetînd încrucișarea cu cele care se hrănesc mai aproape de sol.

7. Ereditatea, sau factorii necunoscuți din care decurge ereditatea, s-a continuat neîntrerupt, rezultatul fiind o succesiune de generații perfect adaptată la viața arboricolă.

8. În cele din urmă, forța conservatoare a selecției naturale a operat constant, tinzînd către păstrarea noilor varietăți, specii și genuri, neîncetînd să acționeze într-o direcție dată, atît timp cît mediul rămîne același.

9. Astfel, pentru a da seamă de originea speciilor, genurilor, familiilor, ordinelor și chiar a clasei, primii pași care au provocat apariția variaţiilor s-au datorat inițial factorilor de evoluție primari direcți și indirecți (neolamarckism), iar stadiile finale s-au datorat factorilor secundari, segregarea și selecția naturală (darwinism)".

Următoarele secvențe, care explică opiniile noastre, le extragem dintr-un studiu recent ${ }^{22}$ :

„Căutînd să explice cauzele metamorfozelor la animale, cineva poate fi tentat să se întoarcă la factorii primari ai evoluției organice, precum schimbarea mediului, fie aceștia cosmici (gravitația), schimbări fizice ale temperaturii, efecte ale creșterii sau scăderii luminii şi umbrei, sub- sau supra-nutriția, schimbări

neîntrebuințarea și transmiterea ereditară a trăsăturilor astfel moștenite „este singura perspectivă pînă acum cercetată, care nu întîmpină deocamdată obiecții serioase” (p. 605-609).

${ }^{20}$ Hints on the Evolution of the Bristles, Spines and Tubercules of Certain Caterpillars etc., în „Proceedings Boston Society of Natural History", XXIV, 1890, p. 493-560, 2 pl.

${ }^{21}$ E. J. Marey, Le Transformisme et la Physiologie Expérimentale, Cours du Collège de France, în „Revue Scientifique”, 2 ème série, IV, p. 818 (Funcția creează organul, mai cu seamă în sistemele osos și muscular.) A se vedea și A. Dohrn, Der Ursprung der Wiebelthiere und das Prinzip des Functionswechsels, Leipzig, 1875. De asemenea, a se vedea și opinia lui Lamarck, p. 295.

${ }^{22}$ On the Inheritance of Acquired Characters inAnimals with a Complete Metamorphosis, in "Proceedings of the American Academy of Arts and Sciences”, Boston, XXIX (n.s. XXI), 1894, p. 331-370; de asemenea, monografia Bombycine Moths, „Memoirs of the National Academy of Sciences", VII, 1895, p. 33. 
decurgînd din existența sau lipsa duşmanilor sau din izolare. Directă sau indirectă, acțiunea acestor factori este evidentă atunci cînd încercăm să explicăm originea sau cauzele metamorfozelor mai însemnate ale animalelor. Astfel se ajunge la ceilalţi factori lamarckieni ai întrebuințării și neîntrebuințării, nevoi noi generînd moduri noi de viață, deprinderi sau funcții care aduc cu sine apariția, dezvoltarea și perfecționarea organelor, conducînd la noi specii şi genuri etc., sau care, în forme metamorfice, pot genera o creștere numerică importantă și o exagerare a aspectelor ce caracterizează stadiile vieții larvale.

[Traducere de Adina Chirilă și Francisc Gafton] 